\title{
Leadership and Global Governance in the Early Twenty-first Century*
}

\author{
CRAIG N. MURPHY' \\ M. Margaret Ball Professar of International Relatians, \\ Department of Political Science, Wellesley College
}

\begin{abstract}
"Global gonernance" is not new. Systems of international regimes regulating and encuraging industrial development across borders bave been characteristic of the last three of the four industrial eras. The outlines of a new industrial era are already clear, but many of the institutions of global governance necesary for that era have not been formed. This is especially the relative to policy questions about labor, the less industrialized regions, and the environment. History suggests that effective new international agreements can be made with the right combination of intellectual leadership with swo types of political leadership: sponsorship of interyovernmental conferences and the benefactorship of experimental international institutions. Relative to environmental issues, intellectual leadership can cone from scientists and scholars of public policy. Sponsorship may come from states with an interest in being considened "first novers" in envinomental affairs. Potential benefactors of costly experimental international envirommental agreements are harder to find. Gonconments of first-moner states may be able to devise means for bardling the redistributive issu's associated with international pollution. Simultaneowly, thy and other govermments will have to find new means of managing other problems associated with the expansion of the industrial system: conflits between capital and labor, between newer and older industries, between more and less industrialized regions of the workh and among leading industrial states.
\end{abstract}

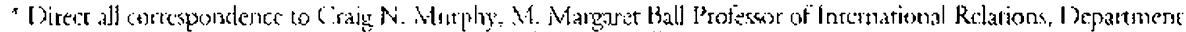

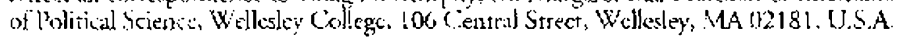




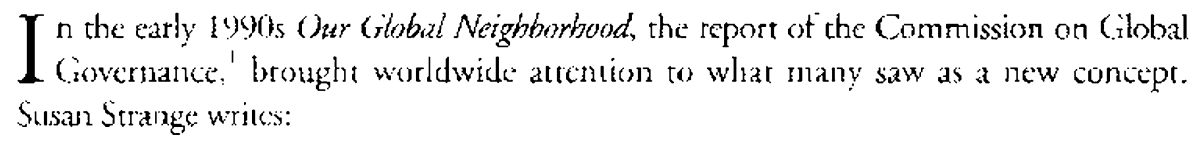

Fver since dhe cort of the Cold War, in many different places around the world. scholars have set up trew centres for the study of something called "global governance" . the sudden mushroming of chese new cintres suggess $\cdots$ the search is on for beter ways of managing socierg and ecommy than has so tar been achieved through the unaided efforts of the individual sarion-siates. Fondations flave readily prowided the resourues for sesearch into "global gover-

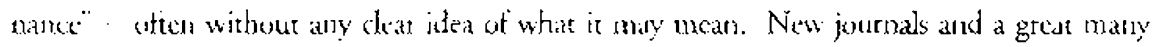
conterinces with simflar titles have proliferated. Ar the same tine. there has been a parallel revival of intckst amoner polioymakers as well as academics it the possibilities for reform of existing incernational oryanizarions from the Iniced Nations wo the World Bank and the Intemicion:al Monctary fiund (Srange 1996, 183).

The tast sentence makes it dear just what the debate over "global governance" is really about. Is is not about creating some fundamentally new sorn of syscon of "world govern. ment." not is it really about manscending the "rhe unaided efforts of the individual nation-states." Rather, ir is abour the creation of a system of effective intergovernmental institutions relevant to the current era of world politics and of the world economy. Gnderstend in that way "global," or more properly "international" governance has been a chatacteristic of wotd affairs ever since the Industrial Revolution.

"Intermational" governarec has becn haracteristic of the last two centuries simply becalls. by their nuture, indestral economics tend to grow beyond the geograptical houndaries in which they first emerged. Marx and Engels wrote of capitalism, that it is "rearing down all Cinese wals" but as Karl Polanyi (1957, 49) noted, any economic sysem bent on an ever-inctedsing division of labot would have the same result; industriadism. even under a command conomy, is bound to tun up against territorial limits creatad by the existing system of sovereignties.

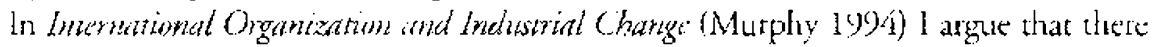
has been a serices of stcpwise chomges in what Henk Overtocek (1993) and othes Amstcram Schual of intermational political conomy scholars call the "paradigmaric scale" of capiralis ind iscrial economies at the core of the world-system. Those economies grew from the regional/natonal economies of the early industrial revolution to the intercontinental natkets that linked the western capitalist countries and the dependent Third World in the Automobile and Jer Age of the 1950) and 1960s. Each transition to a more encompassing industrial order has intitatly becen marked by a period of telativaly slow coo. nemic grouth wortdwike. Throughon that period rapid marketization takes place, the state scoms to rereat, and somzewhat findamentalist versions of kissez-frive liberalism secm to triumph, as they did it the Roaring Twenties and in the Reagan and Tharcher years. 
Up to now, a second, more significant, phase has always followed. It has been marked by the increasing role of a morc socially-oriented liberalism. This second phase (or in Polanyi's terms, the second part of this "double movement") has also been associated with the consolidation of the whole range of "governance" institucions from the international level down to the shop floor. Those institutions have allowed a period of relative peace and relative prosperity over a larger industrial market area in which a new generation of lead industries become dominant.

At the international level the institutions of the nid-cwentieth century Automobile and Jet Age were those that linked the OECD states with each other and with the dependent Third World; at the center was the UN tamily (including the IMF and World Bank) and the GATT. These institutions, in turn wore the innncdiate descendants of the failed League of Nations system, the shild of the European-centered Public International Unions and the turn-of -the-century Inter-American System which helped tegulate and encourage the Second Industrial Revolution, the cra of rapid growth from the 1890s until the First World War. The Public International Lnions and the Inter-American System, in turn, had separate antecedents in the German Customs Union and the pre-Civil War "Annerican States' Union," both of which were understood by many at the time as "international" systems that were facilitating the mid-ninetecnth century era of rapid economic growt b, the Railway Age, in Germany and the nordhern United States, respectively (Murphy 1997a; Deudney 1996).

With this history in mind, one might argue that we are at the beginning of the second phase of an interregnum between the Automobile and Jet Age and the next industrial era of rapid economic growth. We can begin to see the end of the recent era of lassez-faire liberalism. We already can forecast many things about that next era. We know that the core of the global cconomy in that era is tound to be larger than the core of the western industrial conomy in the mid-twentieth century. The new core will likely indude Korea, parts of Southeast Asia, and probably parts of the former Sovier Empire the Czech Republic, Hungary, Fstonia, and only slightly less assuredly, Poland and the other Battic countries). It will include othet regions as well, but probably not all the regions that are now trying to enter that core (China, the whole of Eastern Europe, Latin America, and many states of the Middle East and ercn South Asia).

We also are likely to be accurate if we forecist that some of the international institutions of the next industrial era are in place. The World Trade Organization along with its new regimes for dealing with incellectual property and trade in services are likely to remain the organizations that help create and define the market area in which gonds of the tead indusrries of early rwenticth century will be traded. Arguably, other insticutions -including those defining international industrial standards - ate also in place. But there are two sets of new or reformed international instsutions that are not yet fully develuped.

In the past, the entry into new industrial areas has been natked by the widespread success of that more socially-oricned liberalism mentioned above. Socially-oriented liberalism has helped create international regimes for labor and for the less industrialized world that have encouraged harmony within the newly expanded industrial world order. In the 
past, the emergence of such regines has heen linked to the growing success of egalitarian social novenents - for exanple, women s movements, labor movements, democracy movemuenes, and ant iolonial moxements - whosc mouvaling ideologics have ofien been yuite a bit more molical than the literal incernatonalism which has been the chatacterisois: world vicw underlying "global governance." Nonetheless, this development is consistent with the core propesitions of the liberal internitionalist tradition thar goes back to Adam Smith and Inmanuel Kant.

Borh Smith ard Kant expected that any purarively "republican" state that was captured solely by the interests of profie-takers would not be able so sustain a liberal. highlynproductive economy. Instead, an counomy bascel on carteds, monopolization, ctc. would take hold. as is hard in company-run colutics of Smith's day. This is, of coursc, similar wo the waly Susan Strange (1996) sharacterizes the current world-economy in her recent Retreat of the State. Within the logic of Smith's and Kant's argument. powerful egalizarian social movements help restore the "dirided government," the liberal, republican polities, that allow a liberal comomy or be a source of prosperio; increasing human dignity and peace.

Arguably, the recent partial successes of demosratic movements in the Third World, and the suppost given to such movements by the Onited Nations, may let us anticipate the incernational instutions thas will balance conflices wish the less industrialized world daroughou fue next industrial era (Augelli and Murphy 1995; Boutros-Chali 1995), but those institurons are not filly developed. Nor are the insernational institutions designed w deal with the lahor conflicrs created by a globalizing world cconomy, and the few recent victories of internationallyoricnted latwer novements should, perhaps, have liberal incernarionalises worted. On the leading edge of the yeco-be develoged international institurions of the next industrial cra are international regines on deal with environmencal protilems created by an expanding induscrial world economy. In that field, social movements an point of some victoriss but the new international institutions monain weak. Throughout the rest of this artick. [ will concenuate on environmental regines to illustrate the process by which the renaining internarional institutions of the next industrial era ma be cratiú.

In many ways, the inematimal envitommental issues of the late twentieth century demand to be treated as fundamentally sew problenes of public policy. While Tlomals Malthus may have wotried about che porencial for hutnan owepopulation and Nexandet von Humbols may have promoted the secientific study of the whole earth in the eatly nineternthecentury, it took until after the Sccond World War. when the eminent British biologisn, Julian Fiuxley, became UNES(X) first Executive Director, before environmental issuce becanc a regude lopic of intergevernmental onferences and the subject of

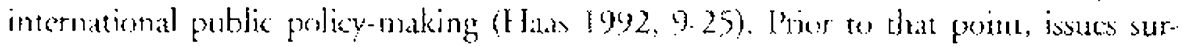

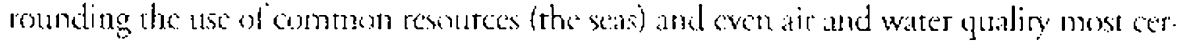
ranly bad bots discussed in international forums and conventions hanning intermational trarke in products manufactured by particuliatly polluting means have existed since che 
turn of the century, but they were treated as matters of particular concern to fishermen. to factory workers, or to the poor in general (Lowe 1921). They were not considercd matters that affected all humanity, ler alone maters that affected all of the living world of which humaniy is just one part.

Yot, when larger-scale envitonmencal issues finally did become a focus of regular international discussion they inirially did so without widespread comment among students of international administration, and without the parties involved saying that they had engaged in any findamentally new form of intergovernmental cooperation. Governments found it easy to include chese new issues under what 1 have called the "moa-regime" under which most intergovernonental agrements dealing with civil matters have been created since the middle of the nineteenth sentury (Murphy 1994, 62).

This arricle starts from the premise that something about the prospects for effecive international envitonnental regulation can be leatned by considering the process through which intcrgovernmental agreements have been formed in ocher vealms over the last century and a half. I begin by identifying the similarities between current international environmental issues and the civil matters that have been the focus of effecive intergovernmental agrements in the past. Then I consider the three types of leadership that have characterized the meta-tegime under which these agreements have been established, as well as the avaibable sources of each rype of leadership relarive to current international environmental issues.

Many analysts atgue that international regimes which require redistribution of property or propeny righrs in order to be effective will be paricutarly difficult to negoriate. In tcrms of the argument which I have outlinc berc, this difficulty should be treated as a likely deficit of one of the three types of leadership. Few potential benefactors of intergovcrnmental cooperation are likely to be willing to bear the burden of underwriting new international instiutuons that provide significant property or propery rights to the lexs advanaged. This probiem characterizes many North-South environmental issues.

However, in the environmental realm the potential deficit of this form of leadership can be mirigated due to the political and technological characteristics of the issues involved. In fact, many international cnvionmental issues may actually be made mare ractable if they are connected to North-South divisions. I suggest teal and hypothetical examples and then conclude by tuming a final lesson from the longer history of internarional civil conperation: We should not expect widespread, effective agreement on intermational emvironmental issues without concurrent agreements to manage other conHicts that arise from industrialism.

\section{INTERNATIONAI. ENVIRONMENTAI. ISSUES AND KINDRED PROBIEMS OF GOVERNANCE WITHOLT GOVERNMENT}

Policy analysts who focus on envitonmental problems that are confined within the boundaries of a single country do not have to cunsider the central problem faced by those trying o devise effective intergovernmental environmental regulation: the need to concen- 
trate on devising relatively inexpensive, cooperative instruments. Within a sovereign state analysts can focus on the politics of convincing legitimate authoritios to legislate wise air-, water-, land-use and resource policies, and then to enforce them using appropriate, legitimate, coercive sanctions and conomic inducerosents in addition to the less-expensive cooperative instruments, such as 1) monitoring prior pro-environment contracts made among citizens and firms, 2) helping different social groups recognize incerests in preserving the envitonment that they share and 3) working with the same groups to design new regimes, new contracts, drat favor the environment - contracis based on shared interests that have already heen recognizad. Mose of the inlergovenmental activity assucialed with the enviroment has used only these three ooperative instruments.

The division of sovereignty among sates makes the effective use of other instruments quite a bit hardcr. The problen is not, as many analysts argue, that the intcrnational system lacks cocrcive authorities.' 'The difficuly arises beaust even when such authorities exist their actions can always be treated as suspect; 10 some states, those actions are bound to be illegitimate. A preponderanc miliary power may be able to force many other states to do its bidding, and so can an intergovernmental organization whose approval is nected to kecp severcly dependem states afloat. In cither case, attulysts might argue that the sovereignty of the target states should he understood as "merely juridical." Nevertheless, even the "merely juridical" sovercignty of the many entities that Robert H. Jackon calls "quasi-states" assures that the external authority's action may at times, be viowed as illegirimate by those it commands. This lack of legitinacy makes such international cuercive anthertices that there are a rather tenuenus basis for the long-em public policies that uost cnvironmental problenus demand. (This also might be: said of international labor agrecnetzls designed en raise labor scandarts in all pares of world.)

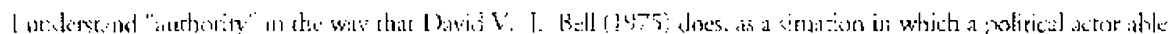

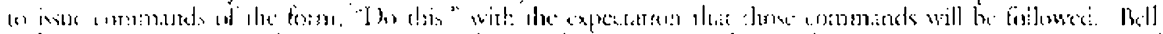

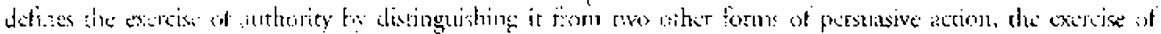

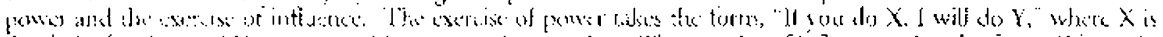

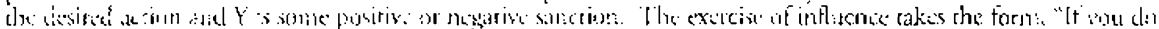

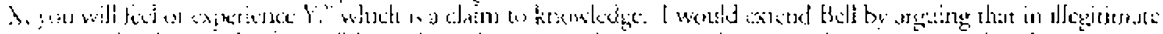

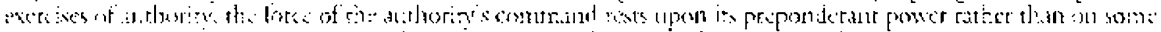

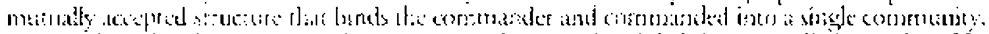

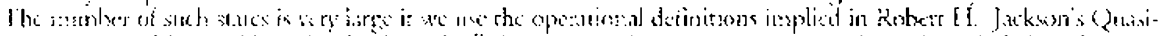

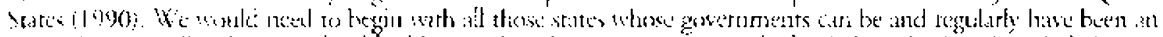

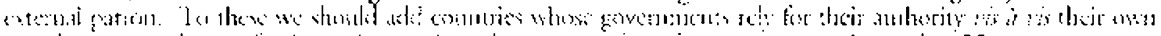

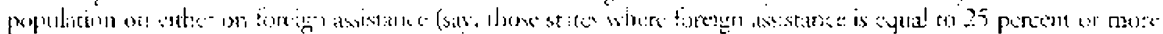

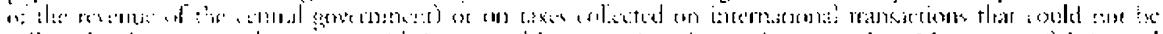

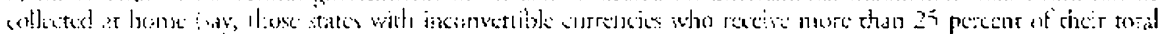

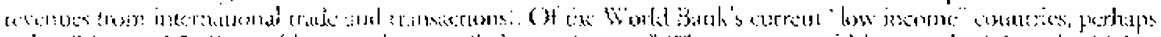

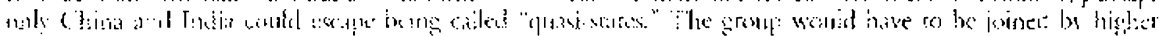

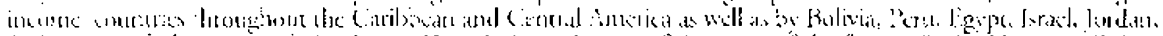

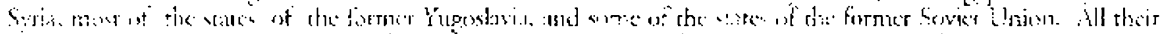

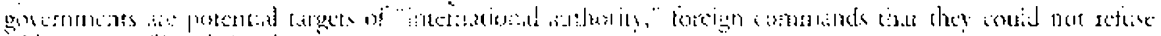

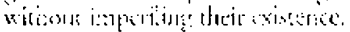

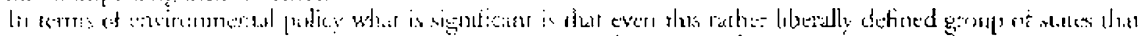

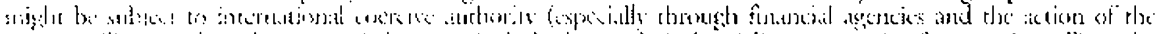

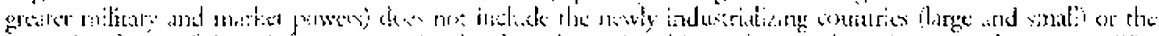

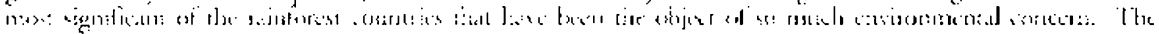

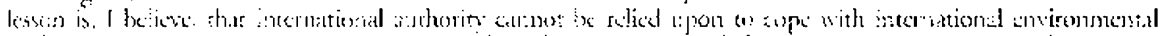

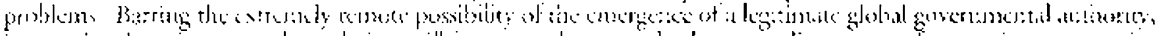

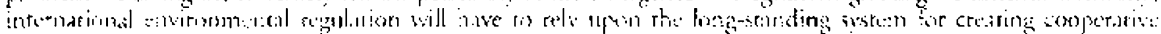

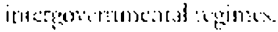


Moreover, urlike the levitimate political authorities that exist in those states whete a regular political process assures that the central authority responds to some version of the collective interest, the authorities that exist at an international level generally have their own particular interests foremost. "The U.S., for example, may speak of the global good whenever it replaces a dictatorship in Panama, but no one would assume that the U.S. will use its authority to foster the "glebal good" by replacing all dictators, including those who happen to be U.S. allies. Sinilarly, the IMF, like any central bank, is designed to serve the good of the financial markets before any other interest.'

Despite the lack of legirimate coercive authority at the international level, governments have creared cffective and legitimate intergovernmental regulatory institucions in a host of ficlds, from accounting to woology. Typically, these insututions carry out rescarch and hold meexings aimed at discovering and promoring common interests among pestentially antagonistic social forces. These have not been limited to narional governments, but have included class, sectorad, and economic-regional interest groups. When governments formally agree wich one another to pursue some form of intergovernmental regulation (which ustially means plodging that private interests within theic societies will be convinced or compelled to act in certain ways), international institutions are often given the task of monitoring adherence to the intergovernmental agreements. Occasionally the intergovernmental bodics atc given the right to demand that member states impose coercive sanctions when prior agreements are violated. Much more frequendy an international cxecutive body is given the responsibility to provide specific services to some or all members, for example, the technical assistance to treasury ministries and central banks provided by the IMF. In many cases, the ulimate recipients of these services are not sates themselves, but economic intcrests that must national govetnmcnts trat as important constituencies."

Thus, the oldest of the global-level intermarional institutions, which date back to the middle of the nineteenth century, originally provided accounting, security, and rechnical scrices that made it possible for an international telegraph and railroad network to be created. The primary beneficiaries of that nework were the large fims involved in the international sale of industrial goods. Similarly, coday some of the most active global incergownmental organizations provide services to the ait transportation and satellite relecommunication industries, which, in turn, creare the plysical infrastructure of the markets used by today's global corporations.

Very early on, global-level international institutions also began providing services that helped manage conflicts berween labor and capital (the regimes designed within and served by the International Labor Organization), and between newer and oldcr economic sectors (for example, by influencing the markets for the products of temperate agriculture including chese, olive oil, rice, wheat, and wine). Later, international institutions concerned with regulating conflicts berween the more industrialized, and less industrialized

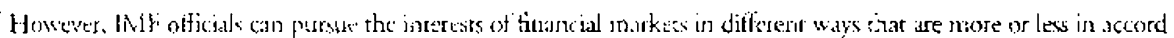

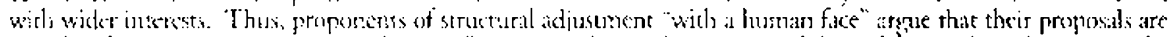

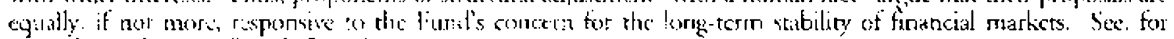

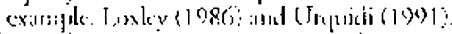

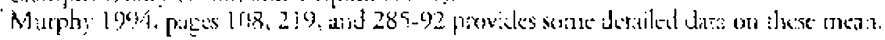


world were added: the world organizations concerned with decolonization and development (Murphy and Augelli 1993).

All of these conflicts dealt with by international institutions before the Second World War resemble most of the pose-war incemational environmental problems of rescurce depletion and pollution in at kast frve ways:

1. All are problerns that have been caused by, ot greatly exacerbated by, the industrial systen.

2. In each case, decisions about long-term irvestmenrs in induscry have a greac deal of intluence, perhaps a determining inftuence, over the degree to which the problem can be managed.

3. As a consequence, in exch case one productive ain of governmental and intcrgowernmental regularory efforts is to shape investment decisions toward norc benignt ends.

1. The investors who furst muve toward these more benign ends an become major allies in the larger regulatory effor bocatese they have an interess in imposing similar investment costs on competitors, as long as that does nor mean that the first-movers lose the advantages conferred on them by their early investment.

5. Once in place, regimes reguiating each of these problems may require litde enforcentent. The srickiness of long-term investments makes the actions required by the regimes a matter of habit, at least umil replacement investments need to be made.

Relative to the problem of the pollution of rivers, lakes, and seas the kcy large investment decisions include choices among different designs and different locations of scwage and garbage disposal systems. industrial plants, and refineries whose effluents may enter the waters. Key decisions also include choices among different designs of ships and tankers that will cross the waters. Other relevant investment decisions have to do with designing and matketing fertilizers used on the lands that drain into the waters. Of course, the list could be made much longer, but it is nor unreasonable to assume that the larger and more long-term investments in a sewage plant, a fertilizer factory, or a ranker, any of which may be from 40 to 60 years will have the nost inpact. Even the most significant of these decisions can be shaped by the governmental and intergovernmental regulatory environnent sinuply because wise firms (whether public or private) always take projections about the regulatory environment intu account before making investments. Shell, for exampte, has a 50 -yar planting trotizon.

In one of the firm's latest cxercises, strategists concluded that the company's decisions should be made so that ir could thrive in two, equally probable, fiture worlds:

In one $\cdot$ regional conflicts plague the world environmental problems are attacked piecenseal, and low prices shape energy ase. In the orber, sustainable development takes hold. Internacionall coepration blossons as combat environental danage and glohal warming.

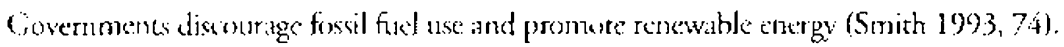

A rricic of Shell's planning process might complain that its own decisions to explore, refine, and transpor fossil tiucls will have a major effect on which of these two scenarios 
becomes a reality, but it may be more fruitful for environmentalists to concentrate on designing public policies that could convince Shell planners that their second, more benign world is the one in which the firm will have to act. "The relevant variables identificd by the planners are, after all, familiar matters of government accion or intcrgovernmental cooperation: combating environmental damage and global warming, discouraging fossil fuel use and promoting renewable energy.

If governments instituted policies toward those ends, Shell would not only respond with its own investments that would help make the goal a reality, the firm would have reason to advocate that all other firms be held to the same, or stricter environmental standards. This interest is characteristic of all the companies that have become "first movers" on environmental issucs, the firms that have been the first to make massive invesunents in technologies that may reduce environmental damage.

Recent policy innovations triggered by the Business Council on Sustainable Development (BCSD) exemplify this process. The BCSD brings together the leaders of a host of the world's largest firms, from Shell to the Dow Chemical Company, to Nippon Stecl, to India's giant TATA, to Volkswagen. These companies have all learned from experience that it can pay to be an environmental first-mover. Gencralizing from their individual experiences, they have convinced the International Organization for Standardization (ISO) to establish a Strategic Advisory Group on the Environment (which, like most ISO groups, essentially represents key companies) to prepare incernational standards for the "eco-efficiency" of industrial products and services. The aim is ro assure that producrs have life-cycle analyses and environmental audits (Schmidheiny $1992,951$.

The self-interest of the BCSD firms is transparent, but it is cnlighened. They belicve that in a globul market of (ivecn consumers and of governments increasingly influenced by the environmental concerns of their publics, ISO standards labeling the environmental desirability of every producr and service will benefit environmental first-movers over all their compericors.

ISO standards that play to the preferences of (ireen consumers represent only one of many ways that the self-interest of firms that have acted as environmental first-movers can be enlisted to exsend the impact of cooperative international institutions involved in cnvironmental regulation. I'erhaps most significantly, the first latge investors in progressive cnviromental practices have cvery interest in becoming the cyes and eats of the regularors, thus strengthening the typically inadequate monitoring systems established through integgovernmental agreenent. Moroover, the longer history of international industrial tegulation suggests that once the investment costs associated with a new regulation have been absorbed, the need for monitoring and taking sanctions against violators diminishes. Conforming with the regulations becomes a mater of habit; alter all, the major decisions, the decisions to make large investments in the cleaner of the available rchnologies, have to be made very rarely. Fuen if a period of economic stagnation gives firms the temporary incentives to cut costs by curring comers, the older habit of investmenc in conformity with "high cost" regulations is likely to return along with the prosperity that woukt make a new round of big investments possible. 
In this light, it is instructive to compare the debates over "international labor legislation" that touk place in Western Europe and the Linited State from the $1870 \mathrm{~s}$ through the 1930s to current debates about global and regional environmental legistation. An the rum of the century. narny of the most prominent economists from all parts of the political spectrum insisted that it would be impossible for the goals of contemporary labor retornats so be achicved short of revolution. They argued that a single state, like Germany, might reduce hours of work or provide social security for a time, but that the lugic of market would assure that German firms would soon lose out to cheaper comperitors. Yet, by 1933, at the lieight of the Depression, James T. Shotwell could wric that most of labor s original goals for the International labor Organization (ILO) had becn achicved (1934, 189,214), and he was not being ironic: laws then on the books in mose industrialized counries mandated the eight hour day, limited child labor, allowed unions co form, and required ruasonable wages, weekly days of resc, equal treatment for foreign workers, equal pay for equal work, and government safety inspections of work places.

In the 1930s. such rules were enforced by interventurnist states supported by an 11.0 that arristly lad grater power to monitor inuertiational adherence to labor standards than it did affer the wat. By the bonming 1960 s adherence to such standards was more a matter of habit. prare of the regularly calculared conts of doing business throughour most of Western Europxi, the U.S., Canada, Australia, New Zealand and Japark.

By the 1980s, when the current long period of relatively slow growth in the world economy was alrcady well under way, Western business groups were again apt to agitace against the cxessive costs associated with labor standatds accepted by the induscrial colantries, and many forms legan sbifring significant production facilitics to places where these standards were nou cniored. Yer, some of the latest analyses of profitable, new large-scale private investment in both older and nower industrialized countries cmphasize that the most successful firms still cond to be attracted to countries where social investment is relarively high and where adherence to intemational labor standards is horh relarively high (compared to other countrics where wages are similar) and where it is increasing. The busintss scheol wisdont used to explain this pattem that modern production processes fequire great investments in human capital, chacation and health, and as a result, no wise investor will risk the capital to build massive now facilities in countries whese gowernments are satisfied with encouraging swearthops (Stopford and Strange 1991). While the cynic in cach of us might easily be able to imagine the ease with whists modern capitalist enterprises might "reinvent" the nineteenth-century production processes that denanded much less investment in human capital (and concomicantly lower labor standats), is woudd probably be wise to bet than the nexe wave of massive ifnestments that will take the workl coonsony ent of the doldrums will be in the newer processes of production that demand more privileged labor.

The reintorcing process of intergovernmental cooperation influencing the large investment decisions of corporate first-movets, who in turn become the advocates, eyes, and

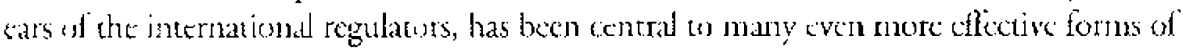


intergovernmental regulation for over a century. The creation of intemational transportation and communicarion networks have convinced firms to invesr in plancs large enough to serve the new market arcas, and to become advocates of international agreements on industrial standards, intellectual property, and rules of trade that facilitate trade within the market area just as international agreement on high labor standards have convinced companies to invest in plants that make adherence to those standards possible, and they have helped assure that the companies that became first-movers on higher labor standards pushed to see them extended to all their international competitors. The very existence of the BCSD suggests that the same process has begun to apply to international environmental standards as well.

\section{INTELLECTUAL IEADERSHIP}

Intergovernmental cooperation can convince invescors to choose cleaner technologies either through incentives, disincentives, or outright bans. Most international environmental regulations ban some actions or elsc test upon the possibility that actions can be banned. As many scholars, but perhaps most notably, Peter M. Haas (1990; 1992) have pointed out that natural scientists have played a key mic in the formation of all international environmental regimes. Whether the problem at hand is the deplecion of the "living resources of the sea," an issue that has been the focus of international regulatory efforts for almost a century (Murphy 1994, 80), or the more tecent efforts to end deplerion of the ozone and control greenhouse gases, scientists projections of the cumulative effects of continuing certain practices have convinced some governments. of the need for inscruational prohibitions.

Natural scientists have not been the only intellectual leaders who have influenced international environmental regulation. As Robert $O$. Keohane $(1984,51-57)$ argues, designing effective international institutions involves fostering new forms of cooperation between states. The intellectual task involves demonstrating to governments that they have shared interests in the outcomes that would $b$ assured by some proposed new international regimes." The intellectual task is one of designing a regime that will avert disasters that the natural sejentiss foresec, or at least will convince governsnents that they are doing what they can to avoid those disasters that could harm their constituents. This work of proposing insciturions is done by economists, lawyers, and diplomats, who, the scientists are apt to complain, oversimplify, ignore interacrion effects, and refuse to recognize the pervasive uncertainty associated with all predictions in the environmental sciences."

There is nothing new about such conflict-ridden wollaboration between natural and

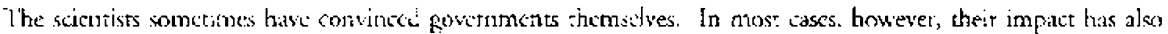

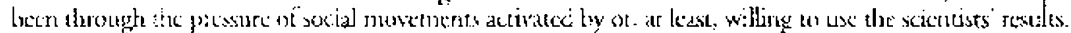

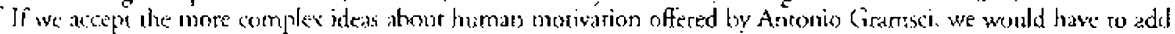
that the intellowial tak cotidd also be one at couvincing governments shar have a chared aspiration to be that

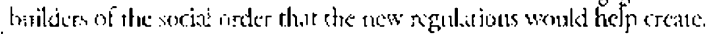

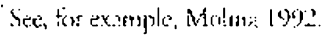


policy scientists. Similar cooperation between intellectual leaders, and similar tensions, have characterized the first stage in the formation of intornational regulatory instiutuons (and, onc could add the public policy process as a whole) since the middle of the ninetoenth cernury.

The differences berween the rwo types ot intellecual leaders have always proved less significant than the values that they rypically share. These can be summarized as preferences for 1 onder and control a desire to make society more suructured and predictable, 2) exonsmic effliene"s, and with it what might be called the 3) political efficiency, that comes from de-emphasizing potcrially divisive aspects of new teguatory regines (Murply 1994, 64-7). These ideas may be essemial goals of any policy analyst attempting $\mathrm{ta}$ discoser previously utrecognized groumds for conperation between sovereign states, but they also help explain why one coological paradigm, what Hazs (1992) calls "scientifu ludism" rather than the available alternatives, has come to underlie the ineernational environmental policy discussim. On the one hand, "scicntific holism" directs attention towatd the "politically efficient" environenentad problems that "threaten global surviva" (Haas 1992, 9), a set of protilems that, to the extent that we believe they exist, leave us link: room to sec differences in interes in the way that (say) problems of wildlife managenent or some of what Has calls "Malthusian paradigm" problems of polturion control might. Yet, on the orher hand, the scientific holises still beticve that more complete planaing, and greater attention to imposing order, wan avert key ecologicil problems, scomething not accepred by what Haas calls rhe "philosophical holist" partdigm.

The convergence around the global problems encouraged by scientific holism has

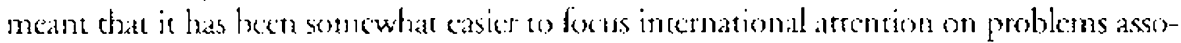
ciated with pollution of the armosphere - ozone deplerion and the cmission of global waming gatses "than on the, typically, less-threatening, regional problems of international pollution of shared berdics of water. As Haas's own study of the Medicrancan suggests, the levels of the various harms culused by pollution of an international waterway have to be tairly high betore there is a lare and cohesive community of intellectual beadcrs including both natural seicneises and policy scicntists, rady to propose designs of internatonal institutions that will ury o linit further damage in a compretensive way.

With knewedge of the longer histon of intermational inscitutions, it is not surprising that die tirse incemational water pollution regines wols be associated with the thansporcation of perrolum and that chey would gtow oile of the International Matitime Organizarion rather than with $:$ new organization concerned with environmental issues. The revan fratern had been mitiated a century earlice by the social movements that

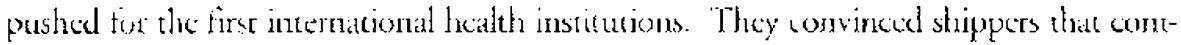
municable discase consld become a problem that would impede shipping, i.e. that socisl movements concerned with public health would sometimes raise stch a hue and ory about stips entering, from disease-ridden areas, that it would be betcer to support a regullarized, predictable intergovernmental systen of quarantines, even though nany shippers (and, ititiall; many medical pofessionals) were nut convinced that the need for such

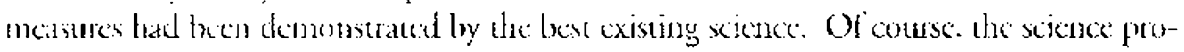


moted by the social movements that advocated quarantine quickly triumphed among all health scientists, in part due to the research carsied out under the initial international health regimes (Murphy 1994, 105). Similarly, in a tumber of cases where international institutions regulating environmental problems have begun with issues that not all scientists suw as rhreatening, the rescarch carried out as a result of preliminary international agreements has quickly led to a stronger international consensus on what needs to be done.

\section{SPONSORSHIP}

No matter how the intcllcctual beaders advocating international environmental agreements hegin, chey always face an uphill struggle to turn any vision of international regulation into reality. This has been true for the designers of all international regimes. Governments, like all habit-driven actors, resist pressure to do new things, especially when the new things require cooperation with forcign citizens over whom they have no control. Keohane(1984)'s image of active incernational cooperation as something that comes about when states pay attencion to the possibility that they may have shared interests is telling. For the most part, the intellectual leaders who propose international regimes feel, quite rightly, that their designs would be in the interest of all the states that they would like to see involved. The problem comes in getring the attention of state leaders, in getting them to sit down, focus on, and discuss the various proposals in order to recognize their shared interests.

Standard diplomatic ptactice provides onc gencric institution suitable for achieving that end, the international conference. Ever since the middle of the ninetcenth century issue-oricnted, functionally-specific international conferences have been central to global and regional govcrianes. Under the nineteenth century conference system the problem of getting gowernuments to focus on proposals for new international regimes that would serve previously-inrecognized shand interests was solved by an institution that many political seientists might consider atavistic: Europe's princes. When Baron Piere de Coubertin ereated the modern Olynapics in 1900 , he was simply following the fashion of Furuge's most powerful aristocrats. Most otten acting on their own behalf, often motivated as much by a nincrecnth century progressive version of liberalism as by aristocratic noblesse oblige. Europe's crowned heads called governments together to form almost all of the first generation of international organizations, from the International Telegraph Union, wo the original Europe-wide rade organization, to the FAO's predecessot (che International institute of Agriculture or 11A), to the International Labor Ofice, to the international police anion, Interpol, which were sponsored by Napoleon III, the Kings of Belgium. Italy, and Cemmany, and the Prince of Monaco, respecrively (Murphy 1994, 7-9).

In the first quarrer of the twenticth century what mighr be called "democratic noblesse oblige" began replacing the aristocratic version. Woodrow Wilson's promotion of the League of Nations had beex anticipated by a half-docess major international conferences 
sponsored by his immediate predecessors and by the presidents of France and Switzerland. All threc coruntijes, even che "isolationist" U.S. continued to play similar roles through 1929, always justifying ute efforc inwolved by referring to the responsibilities for fostering internatuonal cooperation given to those progressive states that already cnjoycd republican constitutions (Murphy 1994, 181-2).

Immediately after the Second World War the major allied victors, the countries that either evenrually enjoycd or were considered for permanent memberships on the L.N Security Council-- Brazil, China, France, the L.K., the U.S., and the U.S.S.R-- split the task of hosting the international conferences needed to create the glotsal institutions of the post-Wer era. "I hen, beginning in the late 1940s, the world organizations, and, at a regional kevel, otder organizations, themsdves became the typical sponsors of intermationa conferences designed to srace now international institutions. The General Assembly hosted the conferences that created UN(TAD and UNIDO), and the OEFC, sponsored the first moves roward a European Community (Muphy 1994, 185-6).

The last two dccudes, when international institutions involved with envirommental issues began to proliferate, have becn a period in which many of the global organizations that had carlier acted as sponsors of now international regimes no longer had the legitima(y to do so. Third World governments often perceived the World Bank as partisan toward ivorthern aconomic interests, while many Vorthern growernments made the same complaint about the General Assembly and orher organizarions in which the Third World had a dear majority." As a result, major environmental conferences have been sponsored hoth by one or more international organizations and by states willing to take a kad in some cuvirommental matters; the sole that Sweden played in the Stockholm Conference. that Cromatry and liance played it dee institutionalizing the World Bank's

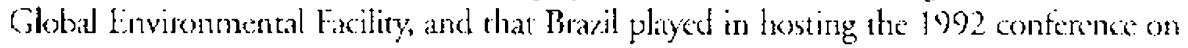
development and the environment.

For the incernational organizations, the morivation for sponsoring such conferences is clear: it is what they are supposed to do. what their members give then resures imernters' dues) to do. Moreover, instituion building is one of the few ways that political enereprencurs within the world organizations -- frou Raul l'tebsisch as Maurice Strong ... have found to put their mark on international affars, and sponsoring international conferenes is one of the tools of institurion building that they have had at hand.

On the other hand, the motivations of national sponsors of incernational conferences may be kess tasy to understand. It appears to involve something more than short-term national scli-interest: some current equivalene of noblesse oblige. In the crivironmental realn it may best be understool as a desire to appear as a national firsc-nnower in cnvironmoncal affairs sther wo sonk national constinency (tor example, voten influcneed by the Cirees politics of Cermany or France) or en the international community as a whole: (a

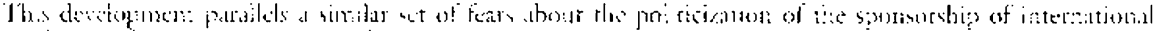

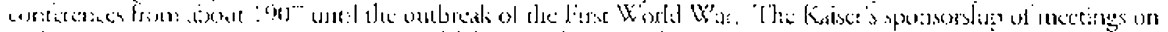

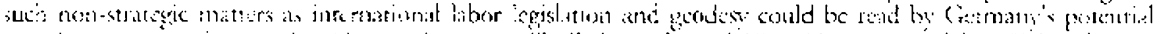

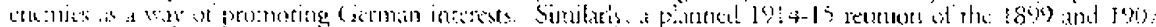

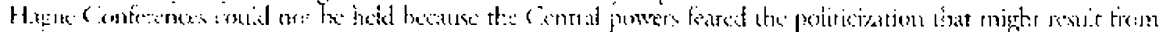

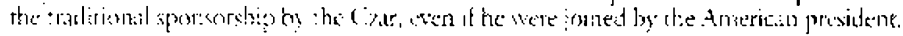


likely part of the Brazilian calculation at different stages in the planning for the $1992 \mathrm{con}$ ference). It is, intially, in this role of encouraging sponsorship that international environmental social movements have teen so significant. Similarly, we might cxpect that relative to another of the "open" issues of the emerging system of global governance-i.c., labor issues-mations with strong, internationally-concerned labor movements may become the sponsors of critically important global conferences. Denmatk attempted to play that role at the Copenhagen summir on social development in 1995, and we should expect similar activities in the future.

As we move into the late 1990 s there may be even less difficulty in finding adequate sponsors for international conferences duat encourage states to recognize and attend to shared global environnental interests. Although financial poblems remain chronic, the world organizations of the UN system have a great deal more legitimacy (they are much less likely to be seen as politicized) than in the 1970 s and $1980 \mathrm{~s}$. Perhaps more significantly, a fairly large number of governments have some interest in being considered firstmovers on international environmental regulation and there is enough overlap that most ropics can be covered. For example, while it may be difficult ro imagine Japan or Norway sponsoring intermational conferences to strengthen international bans on the hunting of sca manmals, it is easy to imagine the L.K. of the U.S. doing so, even lhough they might aarely be kaders in other environmental reatris.

Fven at a regional level, analysts can point to states that are likely to serve as sponsors of international discussions duc to a desire to be seen as first-novets. The tourist industries of southern Europe give those countries such an interest relative to problems of the Mediterrancan. A similar interest is shated by the tourist nations of the Caribbean, and by Australia relative to the Coral Sea. The powe of Green movements give similat morivations to the Nordic comtries and Germany relative to the Baltic and the North Sea, and Japan relative to the waters on its western coasts.

\section{BENEFACTORSHIP}

However, it is one thing to pick many of the bills for a big global meeting, but it is quite another to underwrite international environmental regimes for any length of time. Unfortunately bencfactors willing to pay for the costs of international cooperation over many years have been essential to institutionalization of many international tegimes in the past. In the nineteenth contury and early twentieth century, many of the first generation of major international organizations relied on their original sponsors w pay for the sectecariat that cartied out research, monitored prior international agrecments. and prepared periodic incerational conferences. In fact, the presence of such a bencfacur often seems to have nade the difference between intergovernmental agrement to experiment with a proposed international regime, and the refusal of habic-bound governments to consider the regime, even if good arguments could be made that it was in their interests. After all, if Napoleon III was willing to pick up most of the bill for the Telcgraph Union, Kaiser was willing to pay for the Labor 
OHice, or lidy's Victor Emmanuel ill was willing to underwrite the work of the IIA, no one was willing to object.

In fact, in these sases onc could argue that the organizations and the rogimes to which they concributed only hecane muly instiutionalized as forms of intergovernmental corperation alter political or econonic crises destroyed the capacity of the original benetactor to help underwrife the institution. When the noble benefactor disappeared, member governments had to pust up or shue up. In the case of these organizations, the expcrience of tive on more years of international cooperation nade members quite willing to pay all the costs of linking the international telegraph system, collecting intormation on lator and agriculeure, and linking national police forces.

Since the Scoond World War, many of the inicial costs of new incenational institutions have convinued to be borne by the instututions original sponsots. International organizat tions have acted as the benefactors of international organizations. by providing staff, space, and operating funds for months or even years. Thus, for example, the Unitcd Nations Relicf and Rehabilitation Organizarion provided much of the initial support for ENICEF, the LN Secreariat underwete much of the LiN's arly work on population planning, and the World Bank provided initial funding for hybrids like the International Fund for Agriculumid Thevdopricent.

In many other cases, at single state, the (I.5., acted as the key benefactor. This has especially beco rhe case when the form of international cospetation demanded large transters of liunds, as in the case of European recowery under the OEEC and the Warshall Plan, as well as with the IMF and World Bank. whose earliest subscriprions in internationally negotiable currencies came from the Uniced Scatcs.

Various thoories of legemony have been used ox explain Anterican bencfactorship of Wistern conperation in carly post-War years. Some of the most comvincing are chese that rely on Antonio Cimanseis ideas about the consolidation powet over large popularions and terricorics." America's pose. Wat ladders the argunent goes, were not pursting the shor-term self-interests that underlie so much forcign policy behavior. Instead, they were pursting a more bong-rem aspiration for a wortd structured under Americin leadership, an aspiratisu at the leare of American clice ideology for generations (Augelli and Murphy:

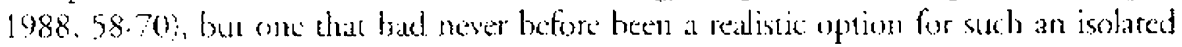
<ournty

Tis comstruct that workd. to creare Amcrican hegemony (in Gramsci's sensc of the word) requited U.S. policy-nakers to be willing to forgo narrow, short-term advancages in order to pursue the collective intcrests of the Western bles. Arguably then, from this point of view, the entire problen of the decline of Ametican hegemony stems from the fact that the accumulared debt of the L.S. government and the long-umatended concems of nuany U.S. citizens mean that now we U.S. government would be in the position to ace as steh a major benctactes of internarional comporation. Moreover, no other state is in the prosition that the L:S. gowernmene was in 1945.

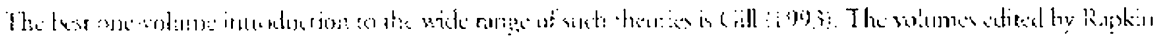

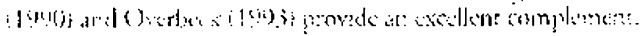


Unfortunately, in the absence of a state willing and able to seek a Gramscian sort of hegemony, it can be extremely difficult to build international institutions that require significant funding. This is one reason that the som-called "North-South dialogue" of the 1970s and early 1980s gor so bogged down. It may very well have been the casc, as the authors of the second Club of Rome Reporn (Tisibergen 1976) and the Brandt Commission $(1980 ; 1983)$ argued, that there were international institutions that costd have served Northern and Southern collective interests in returning to the rapid economic growth of the 1960s, but such institutions could not be formed in the traditional way of getcing governments to agree to something as an experiment and then relying on a benefactor to keep them operating for as long as was needed to prove that the cxperiment was worthwhile. Taken together, the experiments proposed by both groups would have tequired something on the order of a five- or six-fold increase in aid funds from the U.K. Japan, and a number of other donor countries. If one thinks about the size of the lobbying efforr needed by any group that securcs the cquivalent, say, 50 billion dollar aflocation in the L.S. budget each year, one might get a sense of how unrealistic such a call was, especially since this was not the experimental amount to be bornc by a benefacror over a short period of time, but the regular dues to be expected cach year.

Unfortunately, the UNCED Conference made the same unrealistic call for a similat level of ongoing new redistributive funding as part of its proposed global compact (Murphy 1992). Because there is no state that would be able to bear that cost, especially as a benefactor, the longer experience of the creation of effective international regulacion suggess that it may be unrealistic to imagine that the regimes that would rest on that compact will ever be formed (of. Sell 1996). Perhaps the best that can be hoped for in incernational environmental cooperation is agrecment on the relauvely cost-free kind of cco-labeling encouraged by the BCSD. After all, in most recent UNEP trade talks, which tocused on just those sorts of measures, officials were delighred to find that the agenda was one in which "there was so much agrecmenr between industrialized and developing countries." By foctsing on the kind of measures that have been typical of international regulation for over a century, the meeting became one of the lew recem international envirommental forums that "did not degenerate into North-South conflict" (LNFP 1994).

\section{CREATING RESOURCES}

Nonetheless, the longer history of international civil cooperacion suggests that something more may be possible. Many of the international civil institutions created in over the lass century can be thought of as having created resources that were then allocated by politically efficient means that often hid the redistributive element. For cxample, the traditional international intellecrial properry regime not only creared a form of property in the monopoly righes given to inventors, authors, and trademark owners, it also created a duty on the part of patent ownets to "work" their patents in every international market, or else 
lose the right to maincain it. 'I hus, if 'I homas Edison had nos produced his light bulbs in Denmark, or at least, solu his tighnts so that a lecal firm could produce Edison bulbs, the invention would have beern public property. Compared to an absolute system of patents (the kitnd ol sysem that always seems wo be advocated by the echnology leaters, whethet in Britain in the $1850 \mathrm{~s}$, Germany in 1910, or the U.S. today), the actual international regimes have, ihrough the requirement that patents muse be worked, lowered the price of technology to industrializing nations. The current Biodiversity Treary with its sccrions on intellectual property, which will be subjecr su a great deal of interpretation, atso may eventually scrve co creatc similar resources for induscrializing nations, an least ats compared to absoluts system of intellecual property covisioned under the Utuguay Round of the C 3 ATT.

Two generations aftet the tirst ghobal inellectual property regines were put in place, intermational institurions also creuted tesoutces through the dranth-out process of renegotiating Germanys wat dets. Resources creaced by fiat, the war debts themselves. were reduced by fiac. atthough with much hand-waying ahout responsible international financial practices and with the agrement of international bankers and captains of induscry. In was, nenetheless a politically eficient now rlat etsonted the (new) tedistributive cle-

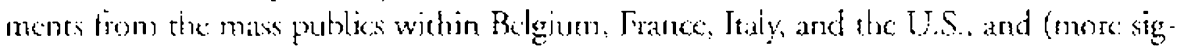
nificandy) from thair elected representatives. many of whom most certainly would have objected.

In 1991, rne discinguithed Mexican economist and long-time policy maker working with and within the [IN, Victor Urquidi (199), 7 ) argued that something sinilar should be done in ordet to assure some level of redistribution to the less industrialized world:

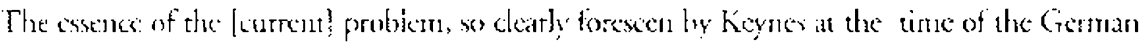
reparatious $\cdots$ is than for the debr to bx repaid $\cdots$ the debors must develop a sutticiently large ixpore surplus.

In the ly80s, the recession-induced collapse of world markets for Third World goods made that impossible. Theretore:

(1.in) a ountriks wene into detault. which mate them indigible for loans or other forms of firnencial assistisnce. Others kept on meeting their interest payments at the expense of growth and developrnent. What ame to be temed the reverse transtar, that is re net vut-transter of finaticial resources from the developing to the industrialized countries, was the equivalent of reparations payments as it a war had been lost. In fact, the war on proverty the great struggle for

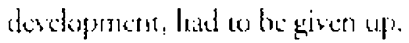

Irquidi's position has not becn taken up in this wholesale torm by advocates of North South comptomises on emvironmental issues; although those relatively small atrempts at "debt for nature" swaps that leave the less industrialized country effective sovereignty over the new nature preserves reflect the same logic.

Oher cases where international instientions have created resources and redistribuced 
them could also be cited. For example, the Bretton Woods institucions used the initial deposits of gold and hard currencies by the U.S. (and the very few othet original members whose money was convertible) to create a pool of loan money that the Fund and Bank immediacly were able to expand both by fiat and by borrowing. As a result of this precedent, the Keymesian proposal to use addirions to Fund reserves as a pool of funds for development assistance remained a hardy perennial in discussions of internarional public finance until the floating exchange rate system appeared in the carly 1970s. The new system made this "reserve-expansion/foreign assistance link" proposal somewhat irrelevant in recent discussions of North-South environmental issues. Nevertheless, it might be a better use of UNEY analysts' time to concentrate on developing proposals of this sort rather than on finding new ways to importune reluctant donors and point out their inconsistency it endorsing multilateral programs without providing the necessary financing.

Programs analogous to the "link" would establish regular (even if initially, small) sources of development finance linked to some growing aspect of the world economy. 'The work of Ruben I?. Mendez (1992) of Yale University and the UNDP suggests some possible dirctions. 'The most interescing are those that could be connected back to the taditional, proven way in which bencfactors have played a role in extending the activicies of world organizations by allowing tew programs to be demonstrated in practice before all staces are required to bear their part of the burden.

A recent Norwegran initiative to impose a carbon tax on North Sea oil (Cooper 1992) is a case that could be easily be linked to such a process. The stares that might be willing to impose such a carbon rax include the "like minded" pro-development oil producers (Canada and Mexico as well as Norway), similar countries with significant roles in the oil trade (for example, the Netherlands and Finland, and perhaps those OPEC members that do not have a strong interest in maximizing current production). They might be joined by the oil companies with executives on the BCSD (Chevron, ENI, and Shell). All mighr agree to impose a smatl unit fee on the oil they process and then give the funds to the $\mathrm{GEF}$. "The retail vendors of oil thus "taxed" would be able to advertise to Green consumers, explaining the major benefit to the environment that derives from a slight increasc in price. Il some firms expectations about the significance of dhe Grocn segment of the market ate correct, then the forces of the market would generate significant development funds. Morcover, governments committed to a Green industrial development path would have an incentive to join in imposing the tax on all the oil sold in their countries. 'This, along with the pressure of consumers, might initiate the kind of bandwagon effect that has never started relative to the 0.7 percent aid target. the unrealistic target that the Club of Rome, the Brand Commission, and the UNCED atl cmbraced.

Of course, one thing that should be noted about such a proposal-which is also true about all the ways in which international institutions have created resources - is the reliance on the special power of some social group, a power that is amplified at the same tine that it is somewhat hidden by the international institurion. In this last example, it is the (hypothetical) puwer of Giccn consumets. In the case of the renegotiation of war 
debes and the original funding of the Bretton Woods institutions it was the power of international financial incerests, a power that was never there to back the "rescrve-expansioniaid link." In the casc of the originad intellecrual property regines, it was a balance of powers of inventors (more concretcly, firms with bigh rescarch and development budgets) with those of the govermments of industrializing countries in which those firms expected to develop new markets.

We might hypothesize that onc of the mon reliable sources of power that could be amplificd by intermational institutions comerned with envirommental issues is that of cnvironmentalist social movencents and cnvironmentaly-concerned citiecns and governments. It may be wortwhile we specutate about all the possible international insticuions that could help silve the redistribution problem associated with creating effective Noth South cnvironmental reginses by thinking of ways to use that power to creatc resmurses.

\section{Absolute Greening at Home in Exchange for Greater Greening Abroad}

Curscut Nerwegian policy can again provisk a starting poisu for thinking about such policy innowations that rely on more than the power of Creen consumers. Linder cur. renr Norwegian ait pollution standards, a number of firms are faced with the problcm of making major investrients to climinate the last five to ten percent of various greenhouse gases discharged from plints that are already some of the cleanest in the world. As is ofen the case with the economics of reducing thluents, the marginal cost of cleaning up these pollutants increases markedly with the percencage of poltutants already disximated Cxnscutenty, the Norweglian firm have neguriated with their government to trinster rechnology and help build plants in China that will reduce substantially more of the same greenhouse gases than similar levels of invescment at home (Sandvold 1993).

Econonists might note that this could be understood as one of many types of suhemes to reduce effluents that could be thought of as involving some kind of exchange of "rights to pollute." Listally. however, that idea applies within a sovercign entio where all polluets can be sue that they will be forced to abide by some sandated. In mose intexna-

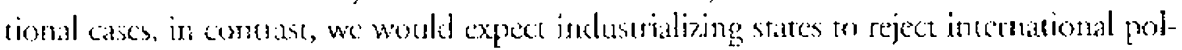
lurion scindards unkss wealthy countries compensare pooret ones for the opportunity costs compliance. In this case, we would expect that the (hinese plants would have concinced to use older, more-polluting practices if the Vorwcgians had not assisted.

The losson can be generalized, at lease as long as emironnencal movements are willing (a) axchange a higher pollution retuction abroad for a lower caduction than they could udewise gec at hones. This probably would noc be seen as a reasonable exchange if the region in quseston was wholly within the counery where envirommental mowements wete

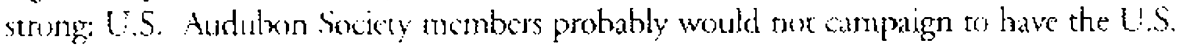
government seil the Cape Cod Nitional Seashore to developers in order to buy and preserve ten ur twency rimes the length of priscine shoreline in southern Mexico. Yot it would be reasconatic for Northern environmentalists to promote schemes afficting common resources that both Nonchem and Souturen countrics pollue 
Many international seas, lakes, and rivers fall into this category. Finnish, Swedish, and Cerman environmentalists. for example, would have reason to support rational kgislation that would allow companics in their countries to invest in cleaning massive amounts of Estonian, Lacvian, Lithuanian, and Russian efluents into the Baltic in lieu of completely diminating effluents from their own, already much cleaner, ships and plants. In fact, one might argue that the North. South logic of such exchanges is so compelling that it may be easier to negotiate effective international regimes for cleaning up bodies of water that lic across North-South divides than to negotiate effective regimes to clean up bodies of water bordered only by states that share a high degree of privilege. For example, effective regimes for the Baluc or the East Asian seas may be casier to achicve than a regime for the Arab/Persian Gulf. On the other hand, in cases where the wealthy states on both sides of a body of water have strong envirommental movements and-usually as a result - a narional commitment to being a first mover in environmental regulation, the process of negotiating international regulations should be casier.

In the many North-South situations, the Northern governments and the Northern environmental movements willing to make the required trade-offs would, by their actions, contribute to what Daniel Jucdney (1923) has dubbet the "world domestic polirics" of "global environmental rescue" in a very concrece way. Rather than just "thinking locally and accing globally." for example, worrying about the pollution of common resources and reducing their local contribution to it, they would be thinking about global (or regional) international problems with the logic of domesric politics, the logic of optimal feasible compromises and of getting the greatest "good" for each expendirure of political resources.

\section{CYCLES OF EFFECTIVE INTERNATIONAL POIICY}

Even after I have invoked this kind of benign Realpolitik that would have Northern environmental groups husbanding their power carefully targeting it to sites around the world, a cricic might still charge that the bulk of $\mathrm{my}$ argument is all too congruent with various relatively rosy liberal scentarios about the interaction between the concerns of industrialists and environmentalists that have been painted by groups like the BCSD and the Japanese Ministry of International Trade and Industry (MITI) when it concluded that, "environmental concerns will drive the next generation of economic growth," and, therefore, more government moncy had to be spent in the "strategic repositioning of Japanese industry" to take advantage of this development (Menon 1992, 5). This kind of argument rests on the assumpeion that conomic growt occurs in waves and that the initial investment environment created by governments influences the nature of successive waves.

Of course, many economises do not accept this view of economic growth. For example, while Richard N. Cooper (1992), who served on the U.S. National Academy of Sciences panel that preparod the L.S. response to UNCED, agrees with his colleagues at 
the BCSD and MIII that some of the actions needed to diminish global warming might provide a net economic gain in the short-run as well as the long-run, he does not believe that all the costly investments required in the short-rum will "pay off" simply by "returning the world economy to a high-growth phase." Because Cooper does not ser gruwth as occurring in cycles, he stes sume of the actions demanded at UNCED as requiring unacceptably large short-run costs.

My own work on the longer history of international institutions makes me believe that there is some validicy to arguments about long waves of economic growth. At least rwice in the past, in Eutepe in the 25 ycars before the First World War and throughout the OECD world in lie 25 years after the Second World War, there appear to have been waves of economic growth and industrial transformation that appear to correspond to the predictions of liberal internationalists going back to Adam Smith. International cooperation helped creare larger market areas which, in turn, encouraged investors to develop new and much more productive technologies (and whole new industries) that led economic growth in these periods of relative peace and telative prosperity. Once before that, in the mid-nimetenth contury's Rajway Age, the integrative institutions of nations that

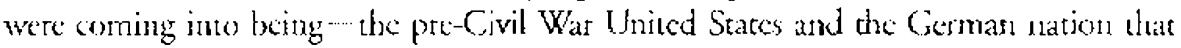
was emerging within the Getman Cascoms Lnion-also secmed to reflect the same pattern.

Unfortunately, the same research suggests that the problem of creating the regulatory environment for a new cyde of growth is nos just one of esablishing a few clever internarional agreemenes and priming the pump with some public invesoment. Before cach of dre prior grouth phases could begin, a whole host of conflices associated with industry had to bo managed. New institutions, many of them international, had wo be ereated to mirigare the conflices over the control of industry that divide labor and capital, the conflicts over componsation in sectors of waning importance that divide older and newer industrial regions, the conflicts over investment opportunities and local autonomy that divide the industrialized and the non-industrialized workd, and the conflicts of prestige that divide industrial contcts.

Long-wave thoorists would argase that intermational envirmnental issues have come to the fore in a period of relative stagtation, the period of show growt that began almost simultaneously with the Stockholm Conference. It certainly may be possible to imagine scenatios that are both rosy and reasonable in which international cnvironmental managentent improves along with the world economy, but we should recognize how broad the international policy agenda must be if we are to make that imagined world real.

At this point, the conflicts over the conrol of industry that divide kabor and capital and tre cunflicts over investment opportunirics and local autonomy that divide the industralized and the non-industrialized world are (along with environmental issues) the most intractable political impedinnens to a deeper and wider "globalization" that would fulfill

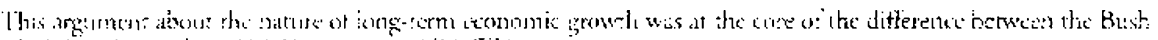

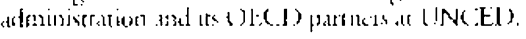


che liberal internationalist vision of Smith or Kant. The last fiftcen years of laissez faire globalization have been marked by increasing ghobal inequalicy, especially between different tegiuns of the world (Koraniewicz and Moran 1997). And, of course, the difficulties in finding benefactors for new international cnvironmental instintions pale in comparisot) to what the difficulties might be in finding benefactors for international institutions with the ability to begin to reverse that trend via redistributive means. This suggests a challenge to econonises to think creatively abous ways in which the rules of the world coonomy could be adjusted so that growth in the core fosters even faster growth in the periphery.

Intcrnational labor agreements, especially agrecments aimed at raising labor standards and establishing rights to organixe in newly industrializing states may, in fact, be easier (w) negociate. But, the history of international institurions in this field should serve as a cauiion. In the past, international regulatory efforts have rarely served working people in all parts of the world. They have, instead, tended so privilege workers in the industrialized world while harming those in the less industrialized nations. It is probably true that a century ago workers in the advanced newly inclustrializing councries of Scandinavia really dict bendit from the self-interested international habor legislation promoted hy the Creman Kaiser to encourage social order within hits nation where both industry and labor movements were more advanced. Equally, it may be trus that workers roday in South Korea or Malaysia will, in the end, greatly benefir from international labor pacts pushed by the American government responding to domestic social forces with interests similar to those that motivated the Kaiser a century ago. But, as Robert W. Cox (1996, 47) reminds us, the first movement for incernational labor regulation was, actually, "part and parcel of the nationalistic movement which was bringing European states into conflict hoth within Furope and nusore especially in the areas of imperial expansion beyond Europe."

Fach of the dimensions of global govennane in the early twenty-first century shoudd be given cqual attention if wc wish ts avoid the breakdown of global governance that took place at the beginning of the wwentieth.

\section{RFFERENCES}

Augelli, Enrico and Craig N. Murphy. 1988. America's Qucst for Supremacy and the Third Wordd: A Grimscian Anulysis. London: Pinter I'ublishers.

Augedli, Entico and Caing N. Murphy. 1995. "Li nuom teoria della pace delle Nazioni unite:" lis A cingustutanmi dalla nascitn delle Nazioni unite, a special issue of Europa/Europe $4(4)$, cds. Gian Giacomo Migone and Olga Re, 9?-121.

Bell, David V. J. 1975. Powes, Influence, and Autbority: An Esiay in Political Linguistics. New Yark: (Oxford ( hniversity Press.

Boutros-Chali, Bocitros. 1995. "Democracy: A Newly-Recoguized Impentive" Global (Bovernance $1: 1)$ 3-11.

Brinde Conmission. 1980. North-South: A Progran for Survital. Cambridge, MA: MIT Press.

Brande Conmision. 1983. Commos Crisis North-South: Cooperation for World Recovery. 
Cambridge, MA: MIT Press.

Cooper, Richard N. 1992. "Public Policy Toward Clobal Warming." Lecture presented to the Wellesley College Department of Economics. March 12.

Cox, Rober W. 1996. "The Idea of International Labor Regulation." In Approaches to World Order. Rotert W. Cox with Timothy J. Sinclair. Cambridge: Cambridge University Press.

Deudney, Daniel. 1993. "Global Environmental Rescue and the Emergence of World Domestic Politics." In The State and Social Power in Global Environmental Politics, eds. Ronnie D. Lipschute and Ken Conca. New York: Columbia University Press.

Deudney, Daniel. 1996. "Building Sovereigns: Authorities, Structures, and Gcopolitics in Philadelphian Systems." In State Sovereignty as a Social Construct, eds. Thomas J. Biersteker and Cynthia Weher. Cambridge: Cambridge University Press, 190-239.

Gill, Stephen, ed. 1993. Gramici, Historical Materialism, and International Relations. Cambridge: Cambridge University Press.

Haas, Peter M. 1990. Saving the Mediterranean: The Politics of International Environmental Copperation. New York: Columbia Uiniversity l'ress.

Haas, Peter M. 1992. "From Theory to Practice: Fcological Idcas and Development Policy." Harvard University, Center for Internarional Affairs Working Paper 92.2.

Jackson, Robert H. 1990. Quasi-States: Sovereignty, International Relations, and the Third World. Cambridge: Cambridge University l'ress.

Koohane, Rober O. 1984 After Hegenony: Cooperation and Discord in the World Political Economy. Princeton: Ptimeton Liniversity Press.

Korzeniewkz, Robents Patricio and Timothy Patrick Moran. 1997. "World-Economic 'Trends in the Distribution of Income, 1965-1992." American Joumal of Sociology 102(4), 1000-39.

Lowe, Boutelle Lllsworth. 1921. The International Protection of Labor. New York: Macmillan.

Loxky, John. 1986. "Alternative Approaches to Srabilization in Africa." In Africa and the International Monetary Fusd, ed. Getald K. Helleiner. Washington, D.C.: International Monetary Fund.

Mendez, Ruben I'. 1992. International Public Finance: A New Perspective on Global Relations. Now York: Oxford University l'ress.

Menon, Bhaskar. 1992. International Document Revieu: The Weckly Newsletter on she linited Nutions. March 6.

Molina, Mario f. 1992. "Science and Policy Interface." In Global Environmental Accords: Implications for Technology, Industry, and International Rclations, ed. Nazli Chourci. Cambridge, MA: Massachusetrs Institure of Technology, United Nations Environmental Programme, Cnited Nation; Development ['rogramme, the World Bank, and the Business Council on Sustainable Development.

Murphy, Crajg N. 1992. "The UN's Capacity to Promotc Sustainable Development: The I cessons of a Yeat that Eludes All Facile Judgment." In The Capacity of the UN System in 1992. Alber Legault. Craig N. Murphy, and W. Ofuatey-Kodjoe. Providence, RI: Academic Council on the UN System.

Murphy, Craig N. 1993. "The UN and the Envitonment After Rio." Joint International Cooperation Research Association/Academic Council on the UN System Symposium on Strengthening the United Nations - Peace and the Enviromment, Tokyo, January.

Murphy, Crag N. 1994. Intentional Organizations and Industrial Change: Global Governance since 1850. New York: Oxford University Press.

Murphy, Craig N. 1997a. "Globalisation in Comparative Historical perspective." In Globalisation in Europe, ed. Roland Axtmann. London: Pinter Publishers.

Murphy, Craig N. 199\%. "Leadership and International Environenental Policymaking." In Saving the Seas: Value, Sizentists, and Intirnational Governanee, eds. I. Atxathea Brooks and 
Stacy D. Van De Veet. Collcge I'ark. Md: Maryland Sea Gram College and Cornell Maritime Press.

Murphy. Craig N. and Enrico Augelli. 1993. "International Institutions, Decolonization, and Development." International Political Science Review 14(1), 71-85.

Overbeek, Ilenk, ed. 1993. Restructuring Ilegemony in the Global Political Economy: The Rise of Transnational Seo-liberalism in the 1980 s. London: Rourledge.

Polanyi, Karl. 1957. The Great Transformation: The Political and Economic Origins of Our Time. Bosron: Beacon Press.

Rapkin, Divid P., ed. 1990. World Leaderstip and Hegemony. Boulder, CO: Lynne Rienner Publishers.

Sandvold, Hdakon. 1993. "Industry-Finvironment-Sustainability." In Global Environmental Accords: Implications for Technology, Industry, and International Relations, ed. Nazli Chourci. Cambtitge, MA: Massachusetts Institute of Technology, United Nations Envimnmental Progtansuse, United Nacions Develupment Programme, the Word Bank, and the Business Council on Sustainable Development.

Schmidheiny: Stephen. 1992. Changing Course: A Global Business Perspective on Developme'nt and the Environment. Cambridge, MA: MIT P'ress.

Sell. Susan. 1996. "North-South Fmironmental Bargaining: Ozone, Climate Change, and Biodiversiry." Global Covernance 2(1), 97-118.

Shotwell, James T., ed. 1934. The Origin of the International Labor Organization. New York: Macmillan.

Sulth, Envily T. 1993. "Growth vs. Environuneme." Buiness Week. 3265, May 11, 66-75.

Stopford, John and Susan Strange. 1991. Rival States, Rival Firms: Competition for World Market Share: Canbridge: Cambridge University Press.

Strange, Susarn, 1996. The Retreat of she State: The Diffision of Pouer in the World Economy. Cambridge: Cambridge University 'tess.

Tinbergen. Jan, coordinator. 1976. Reshaping International Order: A Report to the Club of Rome. New York: Duttoo.

UNEP. 1994. A Successtul Stare 10 Informal Trade-Linvironmenr 'Talks." Geneva: LNEI' Press Release, Febrisary 18.

Urquidi Vicror 1.. 1991 . "Can the Lnired Narions System Meet the Challenges of the World Economy." The Jolu W. Holmes Memorial Lecture to the annual meeting of the Academic Council ou the United Nations System. Mexico City. June. 